\title{
TRPC6 is required for hypoxia-induced basal intracellular calcium concentration elevation, and for the proliferation and migration of rat distal pulmonary venous smooth muscle cells
}

\author{
QINGJIE WANG $^{1 *}$, DONG WANG ${ }^{1 *}$, GAOLING YAN ${ }^{1}$, LING SUN $^{2}$ and CHENGCHUN TANG ${ }^{1}$ \\ ${ }^{1}$ Department of Cardiology, Zhongda Hospital of Southeast University, Nanjing, Jiangsu 210009; \\ ${ }^{2}$ Department of Cardiology, Changzhou Hospital of Nanjing Medical University, Changzhou, Jiangsu 213000, P.R. China
}

Received April 7, 2015; Accepted November 19, 2015

DOI: $10.3892 / \mathrm{mmr} .2015 .4750$

\begin{abstract}
Hypoxia induces pulmonary vasoconstriction and reconstruction in the pulmonary arteries and pulmonary veins (PVs), and elevation of intracellular calcium concentration $\left(\left[\mathrm{Ca}^{2+}\right]_{\mathrm{i}}\right)$ is a primary factor of these processes. In the present study, the role of transient receptor potential cation channels (TRPCs) in mediating the hypoxia-induced elevation of $\left[\mathrm{Ca}^{2+}\right]_{\mathrm{i}}$ in rat distal pulmonary venous smooth muscle cells (PVSMCs) was investigated. Rats with chronic hypoxic pulmonary hypertension $(\mathrm{CHPH})$ were used for in vivo experiments, and PVSMCs were isolated for in vitro experiments. $\left[\mathrm{Ca}^{2+}\right]_{\mathrm{i}}$ was measured using fura-2-based fluorescence calcium imaging. Reverse transcription-quantitative polymerase chain reaction and western blotting were used to detect the mRNA and protein expression levels of TRPCs. Methyl thiazolyl tetrazolium and Transwell assays were used to investigate the proliferation and migration of PVSMCs, respectively. The results of the present study demonstrated that TRPC6 was increased in the distal PVs of CHPH rats, and in PVSMCs exposed to hypoxic conditions $\left(4 \% \mathrm{O}_{2}, 72 \mathrm{~h}\right)$; however, TRPC1 was not. The 1-oleoyl-2-acetyl-sn-glycerol-induced $\left[\mathrm{Ca}^{2+}\right]_{\mathrm{i}}$ elevation was increased in PVSMCs isolated from $\mathrm{CHPH}$ rats and in PVSMCs cultured under hypoxic conditions $\left(4 \% \mathrm{O}_{2}\right.$, 72 h). Hypoxia induced PVSMC $\left[\mathrm{Ca}^{2+}\right]_{\mathrm{i}}$ elevation, proliferation and migration. These alterations were inhibited following TRPC6 knockdown. Results from the present study suggest that TRPC6 expression is increased during chronic hypoxia,
\end{abstract}

Correspondence to: Professor Chengchun Tang, Department of Cardiology, Zhongda Hospital of Southeast University, 87 Dingjiaqiao Road, Nanjing, Jiangsu 210009, P.R. China

E-mail: tangchengchun@medmail.com.cn

*Contributed equally

Key words: chronic hypoxic pulmonary hypertension, pulmonary artery smooth muscle cells, transient receptor potential cation channel, AMP-activated kinase which contributes to $\mathrm{Ca}^{2+}$ entry into the cell, thus promoting proliferation and migration of PVSMCs.

\section{Introduction}

Pulmonary hypertension ( $\mathrm{PH})$ is a serious disease that may result in mobility problems and mortality (1-3). $\mathrm{PH}$ is predominantly caused by hypoxic pulmonary vasoconstriction (HPV) and pulmonary vascular remodeling as a result of exposure to chronic hypoxia $(\mathrm{CH})$ in patients with respiratory disease (4). Elevation of intracellular calcium concentration $\left(\left[\mathrm{Ca}^{2+}\right]_{\mathrm{i}}\right)$ is essential for the initiation of contraction and proliferation of vascular smooth muscle cells (SMCs) $(5,6)$. It has previously been reported that in pulmonary artery (PA)SMCs, hypoxia leads to increases in intracellular $\mathrm{Ca}^{2+}$ release and extracellular $\mathrm{Ca}^{2+}$ influx (7). Calcium influx is predominantly regulated by voltage-dependent $\mathrm{Ca}^{2+}$ channels (VDCCs), and voltage-independent nonselective cation channels, including store-operated $\mathrm{Ca}^{2+}$ channels (SOCCs) and receptor-operated $\mathrm{Ca}^{2+}$ channels (ROCCs). VDCC blockers cannot decrease $\left[\mathrm{Ca}^{2+}\right]_{\mathrm{i}}$ during $\mathrm{CH}$, indicating that $\mathrm{Ca}^{2+}$ influx occurs via signaling pathways other than VDCCs (8-10). In addition to VDCCs, HPV requires an influx of $\mathrm{Ca}^{2+}$ via voltage-independent nonselective cation channels $(6,11-15)$. These channels contribute to membrane depolarization during hypoxia.

Transient receptor potential (TRP) proteins form nonselective cation channels in vascular SMCs $(5,16,17)$. TRPC1 and TRPC6 have been detected in endothelium-denuded intrapulmonary arteries $(12,18,19)$, PASMCs $(6,12,18,20)$, and pulmonary venous SMCs (PVSMCs) $(15,21)$. TRPC1 and TRPC6 form predominantly SOCCs and ROCCs, respectively (22-27). During CH, the levels of TRPC1 and TRPC6 are increased in PASMCs (12) and the $\left[\mathrm{Ca}^{2+}\right]_{\mathrm{i}}$ is increased, indicating that TRPC1 and TRPC6 are important in $\mathrm{CH}$-induced HPV.

Intrapulmonary arteries and veins contribute to the increase in pulmonary vascular resistance during hypoxia (28-31). Therefore, the mechanism underlying the development of hypoxic $\mathrm{PH}$ from the intrapulmonary veins has attracted increasing attention in recent years. TRPC6 expression is increased in rat intrapulmonary veins, as well as in PVSMCs with increased basal $\left[\mathrm{Ca}^{2+}\right]_{\mathrm{i}}$ and store-operated $\mathrm{Ca}^{2+}$ entry (15). 
However, the role of TRPC6 in hypoxia-induced cation entry, and its signaling pathway in PVSMCs, remains to be elucidated.

A previous study demonstrated that TRPC6 is key in mediating hypoxia-induced increases in $\left[\mathrm{Ca}^{2+}\right]_{\mathrm{i}}$ in human PASMCs and that this is linked to cellular energy status via activation of adenosine monophosphate-activated protein kinase (AMPK) (6). The aim of the present study was to determine the effect of hypoxia on $\mathrm{Ca}^{2+}$ entry pathways, particularly on TRPC6 as an ROCC, as well as the relevant activation and regulation signaling pathways in pulmonary veins (PVs) by measuring $\left[\mathrm{Ca}^{2+}\right]_{\mathrm{i}}$ during $\mathrm{CH}$. The proliferation and migration of PVSMCs, which are essential for PV remodeling, were also examined. Data from the present study suggested a key role for $\mathrm{Ca}^{2+}$ entry via TRPC6 in the mediation of $\left[\mathrm{Ca}^{2+}\right]_{i}$ elevation, and the proliferation and migration of rat distal PVSMCs, all of which may be linked to the activation of AMPK.

\section{Materials and methods}

Reagents. Sodium pentobarbital, Hanks' Balanced Salt Solution (HBSS), Earl's Balanced Salt Solution (EBSS), bovine serum albumin (BSA) and dithiothreitol were purchased from Sigma-Aldrich (St. Louis, MO, USA). Collagenase I and papain were purchased from Worthington Biochemical Corporation (Lakewood, NJ, USA). Basal Smooth Muscle Cell Growth Medium-2 was purchased from PromoCell (Heidelberg, Germany).

Ethics statement. Animal experiments conformed to the Guide for the Care and Use of Laboratory Animals published by the US National Institutes of Health (32). The present study was approved by the Ethics Review Board for Animal Studies of Institute of Southeast University (Nanjing, China).

Exposure of rats to $\mathrm{CH}$. CH-induced $\mathrm{PH}(\mathrm{CHPH})$ was produced using an established method (33). Briefly, Sprague Dawley (SD) rats (weight, 250-300 g; Animal Center of Southeast University, Nanjing, China) were randomized into $\mathrm{CH}(\mathrm{n}=12)$ and normoxic control groups $(n=12)$. All animals were fed a standard diet of rat chow and were settled in the laboratory animal room at $21-26^{\circ} \mathrm{C}, 40-70 \%$ humidity and $15-20$ Lux lighting. Rats in the $\mathrm{CH}$ group were exposed to hypoxia for 3 weeks in a chamber that was continuously flushed with a mixture of room air and $\mathrm{N}_{2}$ to maintain $10 \% \mathrm{O}_{2}$. The development of the CHPH model was evaluated by measuring the mean PA pressure (MPAP), right ventricle systolic pressure (RVSP), hematocrit, and weight ratio of the RV/[left ventricle $(\mathrm{LV})+\operatorname{septum}(\mathrm{S})]$.

Rat distal pulmonary vein dissection and PVSMC isolation. Male SD rats (weight, 250-300 g) were used for PV and PVSMC isolation. PVs were isolated from rats maintained in hypoxic and normoxic conditions for western blotting. Thereafter, PVSMCs were enzymatically isolated from rats maintained in normoxic conditions and cultured as described previously $(15,34)$. Briefly, rats were anesthetized with sodium pentobarbital (55 $\mathrm{mg} / \mathrm{kg}$; i.p.) and sacrificed by cervical dislocation. Rat lungs were removed to a bath containing oxygenated modified Krebs solution $(118 \mathrm{mM}$
$\mathrm{NaCl}, 4.7 \mathrm{mM} \mathrm{KCl}, 0.57 \mathrm{mM} \mathrm{MgSO}{ }_{4}, 1.18 \mathrm{mM} \mathrm{KH}_{2} \mathrm{PO}_{4}$, $25 \mathrm{mM} \mathrm{NaHCO}_{3}, 10 \mathrm{mM}$ dextrose, and $1.25 \mathrm{mM} \mathrm{CaCl}_{2)}$ for dissection. Distal pulmonary veins (PVs) (300-350 $\mu \mathrm{m})$ were isolated from the surrounding tissue, and the endothelium was denuded by gently rubbing the luminal surface. The veins were digested at $37^{\circ} \mathrm{C}$ for $20 \mathrm{~min}$ in $\mathrm{Ca}^{2+}$-reduced HBSS supplemented with collagenase type I $(1,750 \mathrm{U} / \mathrm{ml})$, papain $(9.5 \mathrm{U} / \mathrm{ml})$, BSA $(2 \mathrm{mg} / \mathrm{ml})$ and dithiothreitol $(1 \mathrm{mM})$. The solution was centrifuged at $100 \mathrm{xg}$ and $25^{\circ} \mathrm{C}$ for $5 \mathrm{~min}$, and the cells were resuspended in Basal Smooth Muscle Cell Growth Medium-2 containing 10\% supplement mix (Promocell GmbH, Heidelberg, Germany) in an incubator containing $5 \% \mathrm{CO}_{2}$ at $37^{\circ} \mathrm{C}$ for the normoxic group, and $5 \%$ $\mathrm{CO}_{2}, 4 \% \mathrm{O}_{2}$ and $91 \% \mathrm{~N}_{2}$ for the hypoxic group. Cells were arrested in Basal Smooth Muscle Growth Medium-2 with $0.1 \%$ supplement mix $24 \mathrm{~h}$ prior to treatment.

Primers and small interfering RNA (siRNA) design. TRPC1, TRPC6 and $\beta$-actin gene sequences were retrieved from the miRBase database (http://www.mirbase.org/) and used as a reference for designing the polymerase chain reaction (PCR) primers. The primer sequences are presented in Table I. The siRNA were designed with a complementary sequence to rat TRPC1 and TRPC6 mRNA as described previously (35). The designed primers, siRNA and non-target siRNA (siNT) were synthesized by Invitrogen (Thermo Fisher Scientific, Inc., Waltham, MA, USA).

RNA interference. Cells were passaged onto coverslips in $500 \mu \mathrm{l}$ Opti-MEM (Invitrogen; Thermo Fisher Scientific, Inc.) 1 day prior to transfection, and were allowed to reach $40-50 \%$ confluence by the time of transfection. siRNA targeting TRPC1 or TRPC6 were transfected using Lipofectamine ${ }^{\mathrm{TM}} 2000$ (Invitrogen; Thermo Fisher Scientific, Inc.) at a final concentration of $1,000 \mathrm{ng} / \mathrm{ml}$, as described previously and according to the manufacturer's protocols (6). The knockdown effects were examined at $48 \mathrm{~h}$ and the results were compared with the control.

Reverse transcription-quantitative PCR (RT-qPCR). PAs and PVs were de-endothelialized, frozen in liquid nitrogen, and mechanically homogenized. Total RNA was isolated from the tissues and cells using RNAiso Blood (Takara Bio, Inc., Otsu, Japan), according to the manufacturer's protocols. RT-qPCR experiments followed standard protocols. RNA $(1 \mu \mathrm{g})$ was first reverse transcribed to cDNA with random primers using the RT Master Mix kit (Takara Biotechnology, Dalian, China). RT-PCR was performed by using the PrimeScript RT reagent kit (Takara Biotechnology) and the T100 Thermal Cycler (Bio-Rad Laboratories, Inc., Hercules, CA, USA) according to the manufacturer's instructions. The RT-PCR cycling conditions were as follows: $37^{\circ} \mathrm{C}$ for $15 \mathrm{~min}, 85^{\circ} \mathrm{C}$ for $5 \mathrm{sec}$ and $4^{\circ} \mathrm{C}$ for holding.Real-time PCR experiments followed standard protocols using the SYBR Green I qPCR kit (Takara Biotechnology). The PCR cycling conditions were as follows: $95^{\circ} \mathrm{C}$ for $30 \mathrm{sec}$, followed by 40 cycles at $95^{\circ} \mathrm{C}$ for $5 \mathrm{sec}$ and $60^{\circ} \mathrm{C}$ for $31 \mathrm{sec}$. The relative mRNA quantities of target genes were normalized to the values of $\beta$-actin. The results were expressed as fold changes of threshold cycle value relative to the controls using the $2^{-\Delta \Delta \mathrm{Cq}}$ method (36). 
Table I. Primer and siRNA sequences.

\begin{tabular}{ll}
\hline Primer/siRNA & \multicolumn{1}{c}{ Sequences, $5^{\prime} \rightarrow 3^{\prime}$} \\
\hline TRPC1 & F:ATCTTCATGTGCGGTCACAGT \\
& R: TACATCTCAAGCCGCAAGCA \\
TRPC6 & F: TGGCAAGTCCAGCATACCTG \\
& R: CTCCGTGTTTCTGCAGAGGT \\
$\beta$-actin & F: CCCATCTATGAGGGTTACGC \\
& R:TTTAATGTCACGCACGATTC \\
siTRPC1 & GAAUUUAAGUCGUCUGAAA \\
siTRPC6 & GUCCAAAGUCCCUGCUUUA
\end{tabular}

F, forward; R, reverse; TRPC, transient receptor potential cation channels ; si, small interfering.

Western blotting. Following serum starvation (0.1\% supplement mix) for $24 \mathrm{~h}$, cells were cultured in normoxic $\left(5 \% \mathrm{CO}_{2}\right)$ or hypoxic $\left(5 \% \mathrm{CO}_{2}, 4 \% \mathrm{O}_{2}\right.$ and $\left.91 \% \mathrm{~N}_{2}\right)$ conditions. Total proteins were prepared at the indicated time-points using the protein extraction kit (TDY Biotech Co., Ltd., Beijing, China), containing complete protease inhibitor (Roche Diagnostics, Indianapolis, IN, USA). Western blotting was conducted as described previously (6). Cell lysates with equal quantities of protein $(50 \mu \mathrm{g})$ were separated by $10 \%$ sodium dodecyl sulfate-polyacrylamide gel electrophoresis and transferred electronically to polyvinylidene difluoride membranes. The polyvinylidene fluoride membranes (Millipore, Darmstadt, Germany) were blocked with 5\% non-fat milk powder in 1X TBS containing $0.1 \%$ Tween 20 for $1 \mathrm{~h}$ at room temperature, and were then incubated with anti-TRPC1 (1:500; cat. no. sc15055; Santa Cruz Biotechnology, Inc., Dallas, TX, USA), anti-TRPC6 (1:500; cat. no. sc19196; Santa Cruz Biotechnology, Inc.) and anti- $\beta$-actin (1:5,000 cat. no. A5441; Sigma-Aldrich) at $4^{\circ} \mathrm{C}$ overnight. The membranes were subsequently incubated with horseradish peroxidase (HRP)-conjugated anti rabbit secondary antibodies (1:5,000; cat. no. s004; TDY Biotech Co., Ltd.), HRP-conjugated anti-goat secondary antibodies (1:5,000; cat. no. s008; TDY Biotech Co.,Ltd.), or HRP-conjugated anti-mouse secondary antibodies (1:5,000; cat. no. s001; TDY Biotech Co., $\mathrm{Ltd})$, for $1 \mathrm{~h}$ at room temperature. The blots were visualized using a Chemiluminescent Substrate kit (Pierce; Thermo Fisher Scientific, Inc.). The membranes were scanned and the sum optical density was quantitatively analyzed by Quantity One software v4.62 (Bio-Rad Laboratories, Inc.).

Immunofluorescence staining. After washing three times in phosphate-buffered saline (PBS), cells were fixed with $4 \%$ paraformaldehyde at room temperature for $20 \mathrm{~min}$. Cells were washed in PBS and treated with $0.3 \%$ Triton X-100 for 5 min on ice. Then cells were blocked with 5\% FBS for 30 min at room temperature and incubated with anti-smooth muscle $\alpha$-actin (1:100, Sigma-Aldrich) at $4^{\circ} \mathrm{C}$ overnight. Cells were washed three times in PBS and incubated with Alexa Fluor 488-conjugated second antibody (Cell Signaling Technology, Beverly, MA, USA) for $1 \mathrm{~h}$. Finally, cells were washed with PBS, stained with DAPI (Sigma-Aldrich) and observed under microscope (Olympus IX71, Tokyo, Japan). Calcium imaging. Cells were
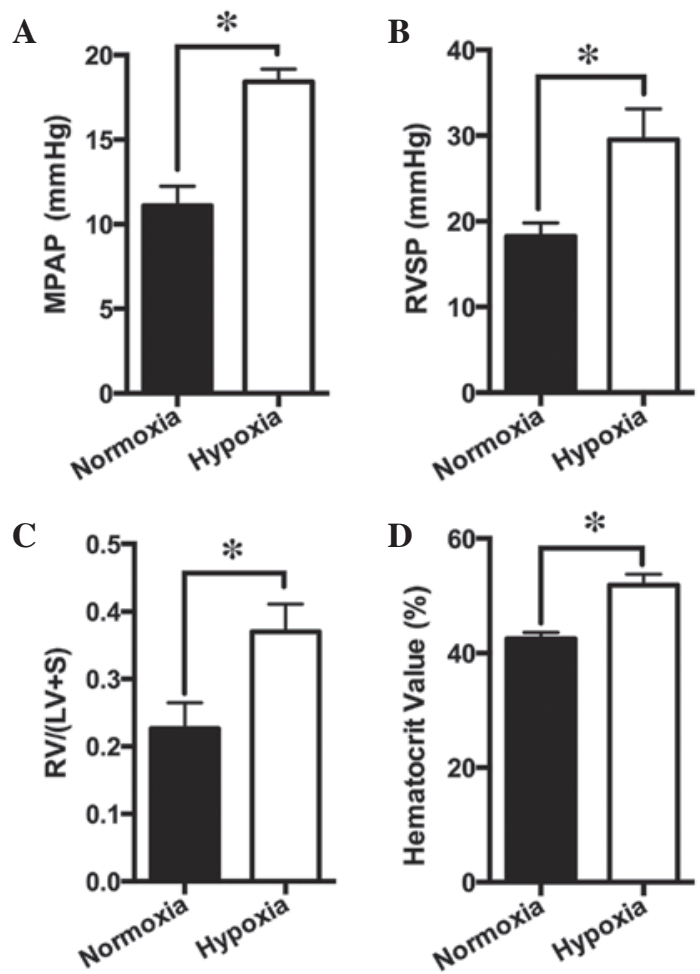

Figure 1. Effects of chronic hypoxia on PA and right-side heart pressures. Animals were exposed to normoxia or hypoxia $\left(10 \% \mathrm{O}_{2}\right)$ for 21 days. The (A) MPAP, (B) RVSP, (C) RV/(LV + S), and (D) hematocrit are presented as the mean \pm standard error of the mean $\left(n=12,{ }^{*} \mathrm{P}<0.05\right)$. PA, pulmonary artery; MPAP, mean PA pressure; RV, right ventricle; RVSP, right ventricle systolic pressure; $L V$, left ventricle; $R V /(L V+S), R V / L V+$ septum mass ratio.

washed with EBSS, and a stock concentration of fura-2 AM [0.01 g in $50 \mu$ l dimethyl sulfoxide (DMSO); Molecular Probes; Thermo Fisher Scientific, Inc.]was prepared. A mixture of $1 \mu \mathrm{l}$ stock dye in $200 \mu \mathrm{l}$ EBSS was applied to the cells and incubated for at least $30 \mathrm{~min}$ prior to observation. Prior to placing the coverslips into the recording chamber, the cells were rinsed in normal Tyrode's medium (containing $137 \mathrm{mM} \mathrm{NaCl}, 5.4 \mathrm{mM}$ $\mathrm{KCl}, 1.2 \mathrm{mM} \mathrm{MgCl}{ }_{2}, 1.8 \mathrm{mM} \mathrm{CaCl}_{2}, 1.2 \mathrm{mM} \mathrm{NaH}_{2} \mathrm{PO}_{4}$, $10 \mathrm{mM}$ D-glucose, $20 \mathrm{mM}$ HEPES and $10 \mathrm{mM}$ taurine), in order to remove residual dye. Data acquisition was performed using an IX71 microscope (Olympus Corporation, Tokyo, Japan). Fluorescent changes in fura- 2 were measured with double wavelength excitation at 340 and $380 \mathrm{~nm}$, and emission at a wavelength of $510 \mathrm{~nm}$. Absolute $\mathrm{Ca}^{2+}$ was calibrated using Fura-2 Calcium Imaging Calibration kit (Invitrogen; Thermo Fisher Scientific, Inc.). Changes in $\mathrm{Ca}^{2+}$ concentration in the region of interest were calculated according to a ratio of 340/380. Time lapse recording initially captured the images at $1 \mathrm{sec}$ intervals; however, in order to minimize cell image bleaching in the long experimental protocol, 2 or $3 \mathrm{sec}$ intervals were applied in the experiments. The majority of the data presented in the figures were acquired at $3 \mathrm{sec}$ intervals. The following chemicals were used for calcium imaging: $5 \mu \mathrm{M}$ nifedipine, $5 \mu \mathrm{M}$ SKF96365, $100 \mu \mathrm{M}$ OAG and $10 \mu \mathrm{M}$ U73122 (Sigma-Aldrich), and compound C (40 $\mu \mathrm{M}$, Calbiochem; Merck KGaA, Darmstadt, Germany). The chemicals were dissolved in ethanol or DMSO and made as required on the day of experiments. Ethanol and DMSO were tested alone in controls at the same vehicle concentration and had no effect. 
A
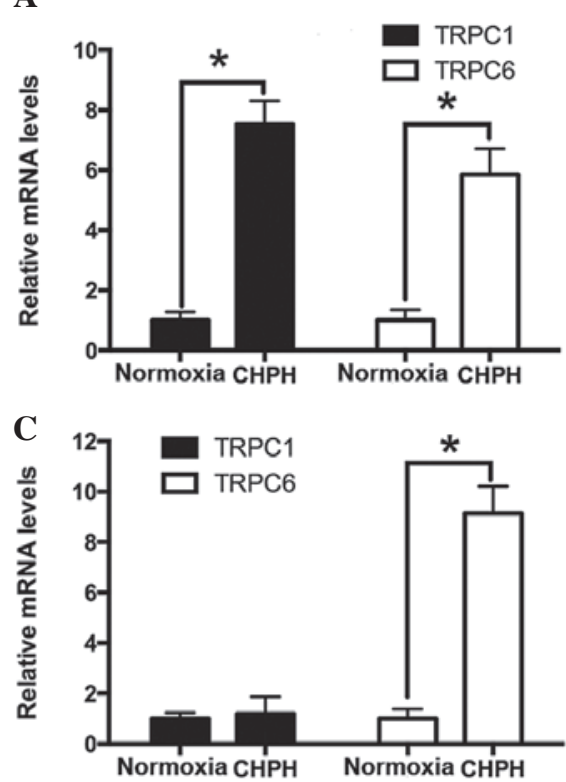

B

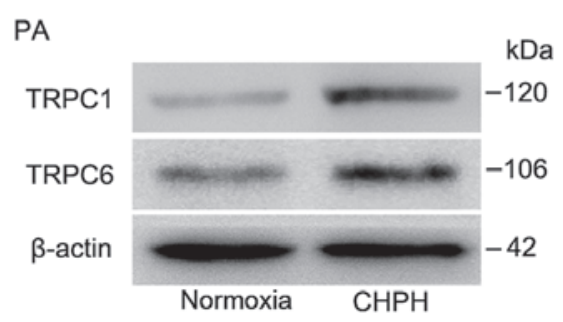

D

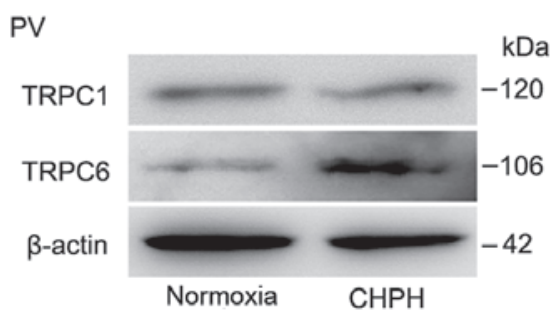

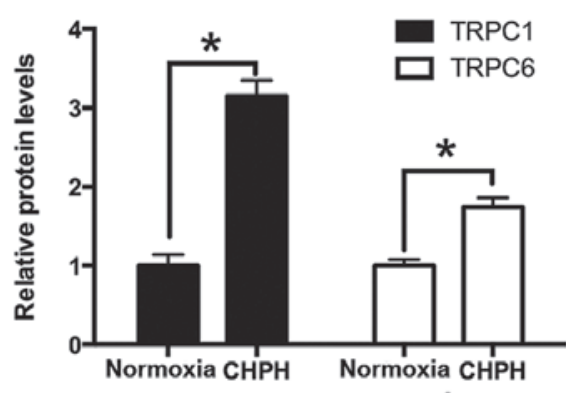

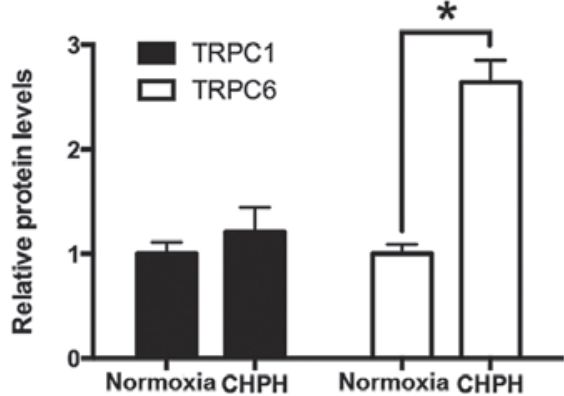

Figure 2. Expression of TRPC1 and TRPC6 in the distal PA and distal PV of normal and CHPH rats. TRPC1 and TRPC6 mRNA and protein expression levels in the (A and B) distal PA and (C and D) distal PV were determined by reverse transcription-quantitative polymerase chain reaction and western blotting, which was semi-quantified by densitometry. Total $\beta$-actin was used for normalization. Data are presented as the mean \pm standard error of the mean $\left(n=3\right.$, ${ }^{*} \mathrm{P}<0.05$ ). TRPC1, transient receptor potential cation channel 1; TRPC6, transient receptor potential cation channel 6; CHPH, chronic hypoxic pulmonary hypertension; PA, pulmonary artery; PV, pulmonary vein.

A

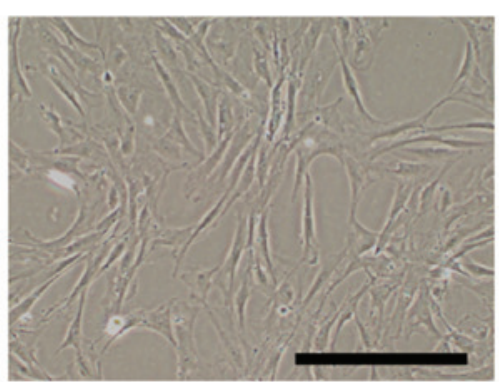

C

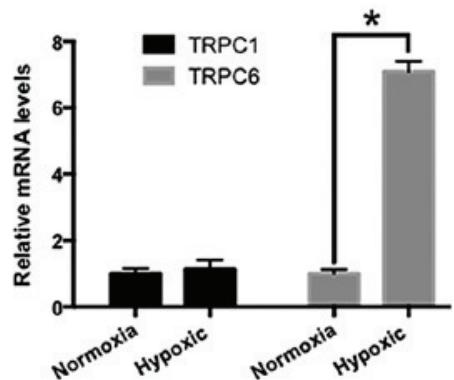

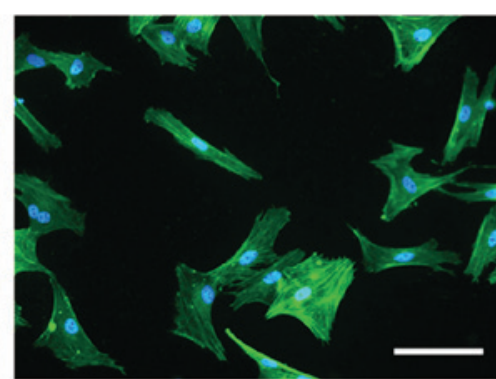

D

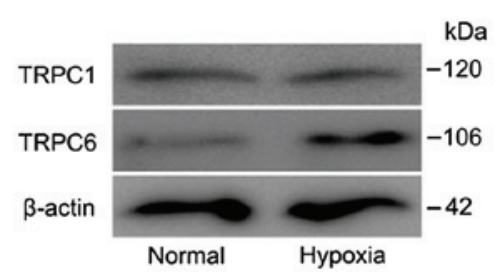

B
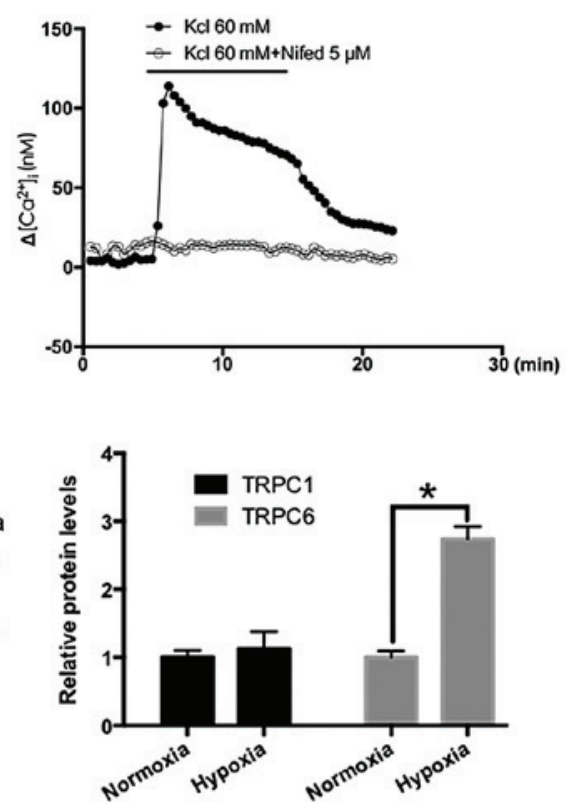

Figure 3. Expression of TRPC1 and TRPC6 in cultured rat distal PVSMCs under hypoxic conditions. (A) Characteristics and identification of rat distal PVSMCs. Cell morphology was investigated under microscopy. PVSMC were fixed and immunofluorescence staining was conducted with primary antibodies against smooth muscle $\alpha$-actin (green). The nuclei were labelled with 4',6-diamidino-2-phenylindole (blue). Scale bar, $50 \mu \mathrm{m}$. (B) Representative traces of the time course of $\left[\mathrm{Ca}^{2+}\right]_{\mathrm{i}}$ responses to $\mathrm{KCl}(60 \mathrm{mM})$ with or without nifedipine in PVSMCs. TRPC1 and TRPC6 mRNA and protein expression levels under normoxic and hypoxic conditions as determined by $(\mathrm{C})$ reverse transcription-quantitative polymerase chain reaction and (D) western blotting, which was semi-quantified by densitometry. Total $\beta$-actin was used for normalization. Data are presented as the mean \pm standard error of the mean $\left(\mathrm{n}=3\right.$, $\left.{ }^{*} \mathrm{P}<0.05\right)$. TRPC1, transient receptor potential cation channels 1; TRPC6, transient receptor potential cation channel 6 ; $\left[\mathrm{Ca}^{2+}\right]_{\mathrm{i}}$, intracellular calcium concentration; PVMSC, pulmonary vein smooth muscle cell.

Hypoxia medium was applied using gas bubbled media $\left(\mathrm{O}_{2}\right.$ level, $20 \mathrm{mmHg}$ ) as described previously (6). Briefly, Tyrode's solution was bubbled into para-film-sealed bottles. Then the medium was applied through a $0.8 \mathrm{~mm}$ ID tube driven by a peristaltic pump (minipuls 3, Gilson, Inc., Middleton, WI, USA) in which fluid flow to the recording chamber (RG 26; 

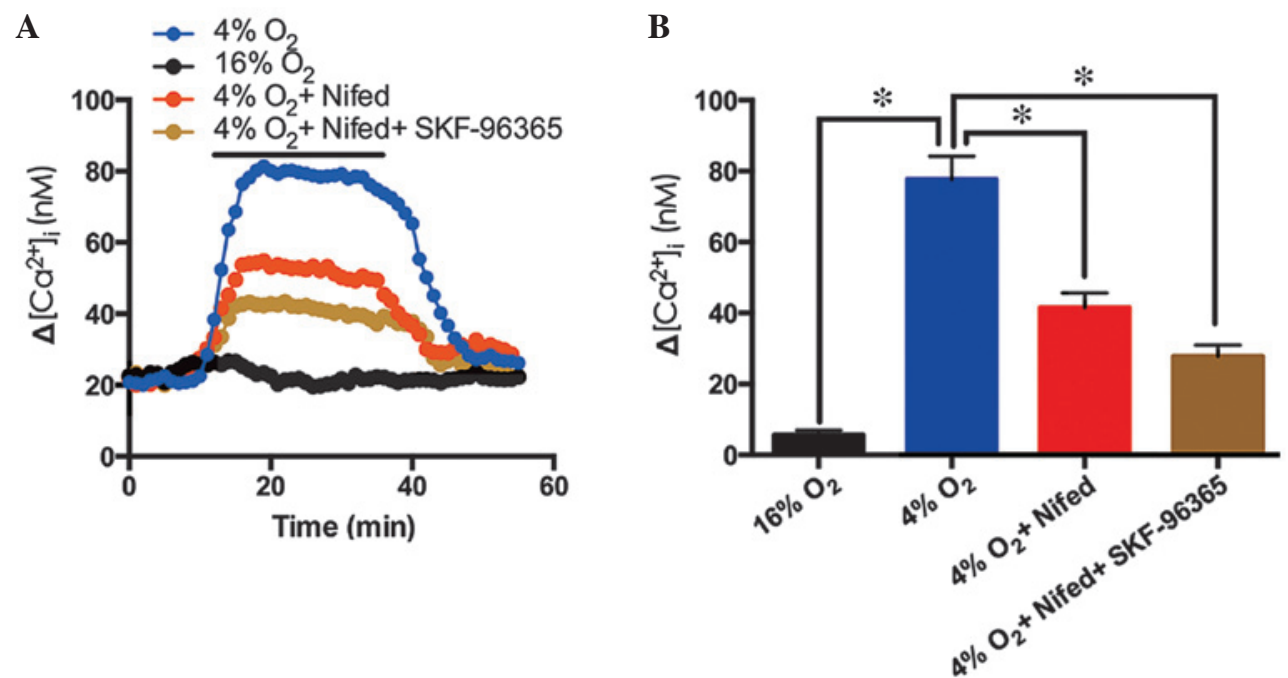

Figure 4. Response of $\left[\mathrm{Ca}^{2+}\right]_{\mathrm{i}}$ to acute hypoxia in PVSMCs. (A) In the control condition, cells were perfused with sustained normoxia $\left(16 \% \mathrm{O}_{2}\right.$; black; $\mathrm{n}=6$ experiments in 103 cells). Time course of $\left[\mathrm{Ca}^{2+}\right]_{\mathrm{i}}$ prior to and following hypoxia $\left(4 \% \mathrm{O}_{2} ;\right.$ blue; $\mathrm{n}=6$ experiments in 108 cells) in PVSMCs. Effect of $5 \mu \mathrm{M}$ nifedipine on the response of $\left[\mathrm{Ca}^{2+}\right]_{\mathrm{i}}$ to hypoxia is indicated in red ( $\mathrm{n}=6$ experiments in 125 cells). Effect of $5 \mu \mathrm{M} \mathrm{SKF}-96365$ and nifedipine on $\left[\mathrm{Ca}{ }^{2+}\right]_{\mathrm{i}}$ under hypoxic conditions is indicated in brown ( $\mathrm{n}=6$ experiments in 105 cells). (B) Average peak change in $\left[\mathrm{Ca}^{2+}\right]_{\mathrm{i}}$ from obtained cells. Data are presented as the mean \pm standard error of the mean $(" \mathrm{P}<0.05)$. $\left[\mathrm{Ca}^{2+}\right]_{\mathrm{i}}$, intracellular $\mathrm{Ca}^{2+}$ concentration; PVMSC, pulmonary vein smooth muscle cell; Nifed, nifedipine.

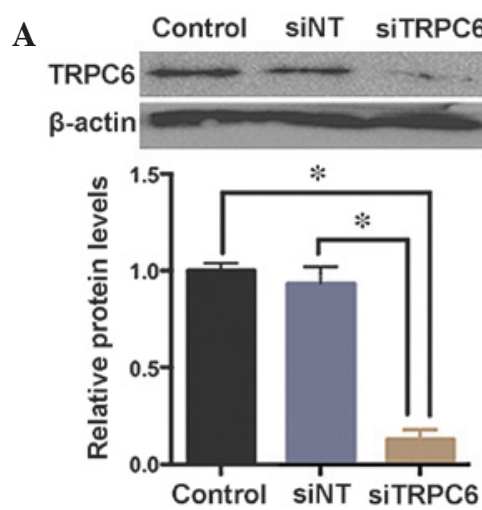

C

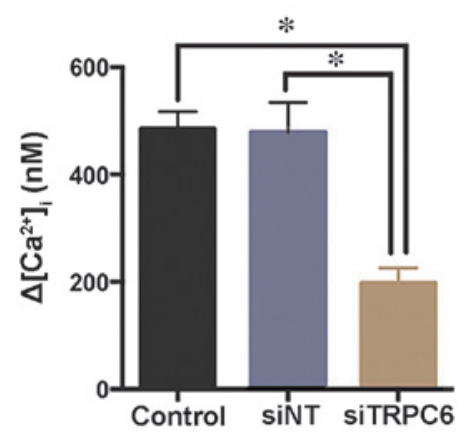

B
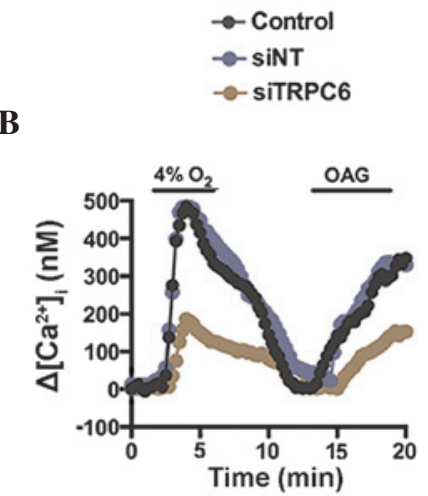

D

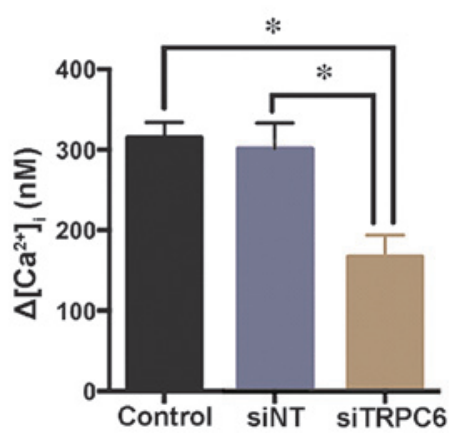

Figure 5. Effect of siTRPC6 transfection on the response of $\left[\mathrm{Ca}^{2+}\right]_{i}$ to acute hypoxia and OAG in PVSMCs. (A) Protein expression levels of TRPC6 in PVSMCs treated with siNT or siTRPC6 were determined by western blotting and semi-quantified by densitometry. Total $\beta$-actin was used for normalization. (B) Change in $\left[\mathrm{Ca}^{2+}\right]_{\mathrm{i}}\left(\Delta\left[\mathrm{Ca}^{2+}\right]_{\mathrm{i}}\right)$ following treatment with hypoxia $\left(4 \% \mathrm{O}_{2}\right)$ or OAG $(100 \mu \mathrm{M})$ in the control group (black; $\mathrm{n}=3$ experiments in 69 cells), siNT group (blue; $\mathrm{n}=3$ experiments in 62 cells), and siTRPC6 group (brown; $\mathrm{n}=3$ experiments in 58 cells). Summary of TRPC6 knockdown responses of cells treated with (C) hypoxia and (D) OAG. Data are presented as the mean \pm standard error of the mean ("P<0.05). TRPC6, transient receptor potential cation channel 6; OAG, 1-oleoyl-2-acetyl-sn-glycerol; PVSMC, pulmonary vein smooth muscle cell; siRNA, small interfering RNA; siNT, non-targeted siRNA.

Warner Instruments, LLC., Hamden, CT, USA) was controlled at a rate of $5 \mathrm{ml} / \mathrm{min}$.

Proliferation assays. An MTT assay was used to determine the proliferation rate. Briefly, cells were seeded at a density of 5,000 per well in 96-well cell culture plates and starved with $0.1 \%$ FBS in SMC Growth Medium-2 for $24 \mathrm{~h}$. Cells were incubated under normoxic or hypoxic conditions. After $24 \mathrm{~h}$, $20 \mu \mathrm{l}$ of MTT ( $5 \mathrm{mg} / \mathrm{ml}$; Sigma-Aldrich) was added to each well for $3 \mathrm{~h}$ incubation. Subsequently, cells were dissolved 
A

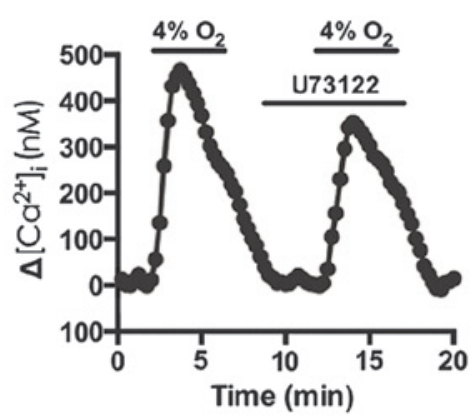

B

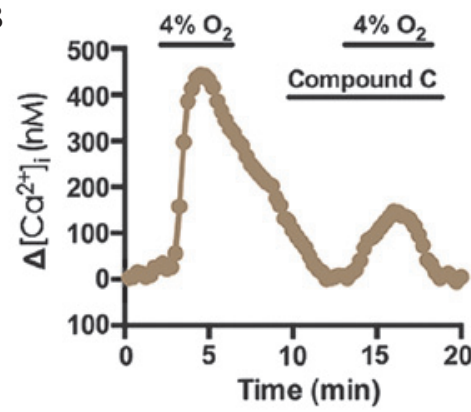

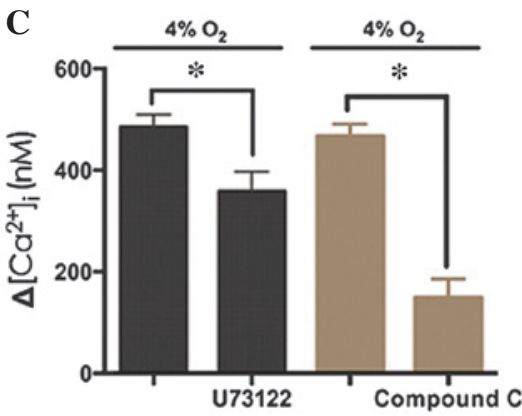

Figure 6. Hypoxia-induced $\left[\mathrm{Ca}^{2+}\right]_{\mathrm{i}}$ elevation in PVSMCs is independent of PLC. (A) Effects of $10 \mu \mathrm{M} \mathrm{U73122}$, an antagonist of PLC, on changes in $\left[\mathrm{Ca}^{2+}\right]_{\mathrm{i}}\left(\Delta\left[\mathrm{Ca}^{2+}\right]_{\mathrm{i}}\right)$ under hypoxic conditions ( $4 \% \mathrm{O}_{2}$; black; $\mathrm{n}=3$ experiments in 72 cells). (B) Effects of $40 \mu \mathrm{M}$ compound $\mathrm{C}$, an antagonist of AMPK, on $\Delta\left[\mathrm{Ca}^{2+}\right]_{\mathrm{i}}$ under hypoxic conditions ( $4 \% \mathrm{O}_{2}$; brown, $\mathrm{n}=3$ experiments in 76 cells). (C) PLC and AMPK inhibition of $\Delta\left[\mathrm{Ca}^{2+}\right]_{\mathrm{i}}$ under hypoxic conditions. Data are presented as the mean \pm standard error of the mean ( $\mathrm{P}<0.05)$. $\left[\mathrm{Ca}^{2+}\right]_{\mathrm{i}}$, intracellular $\mathrm{Ca}^{2+}$ concentration; PVMSC, pulmonary vein smooth muscle cell; PLC, phospholipase C; AMPK, AMP-activated protein kinase.

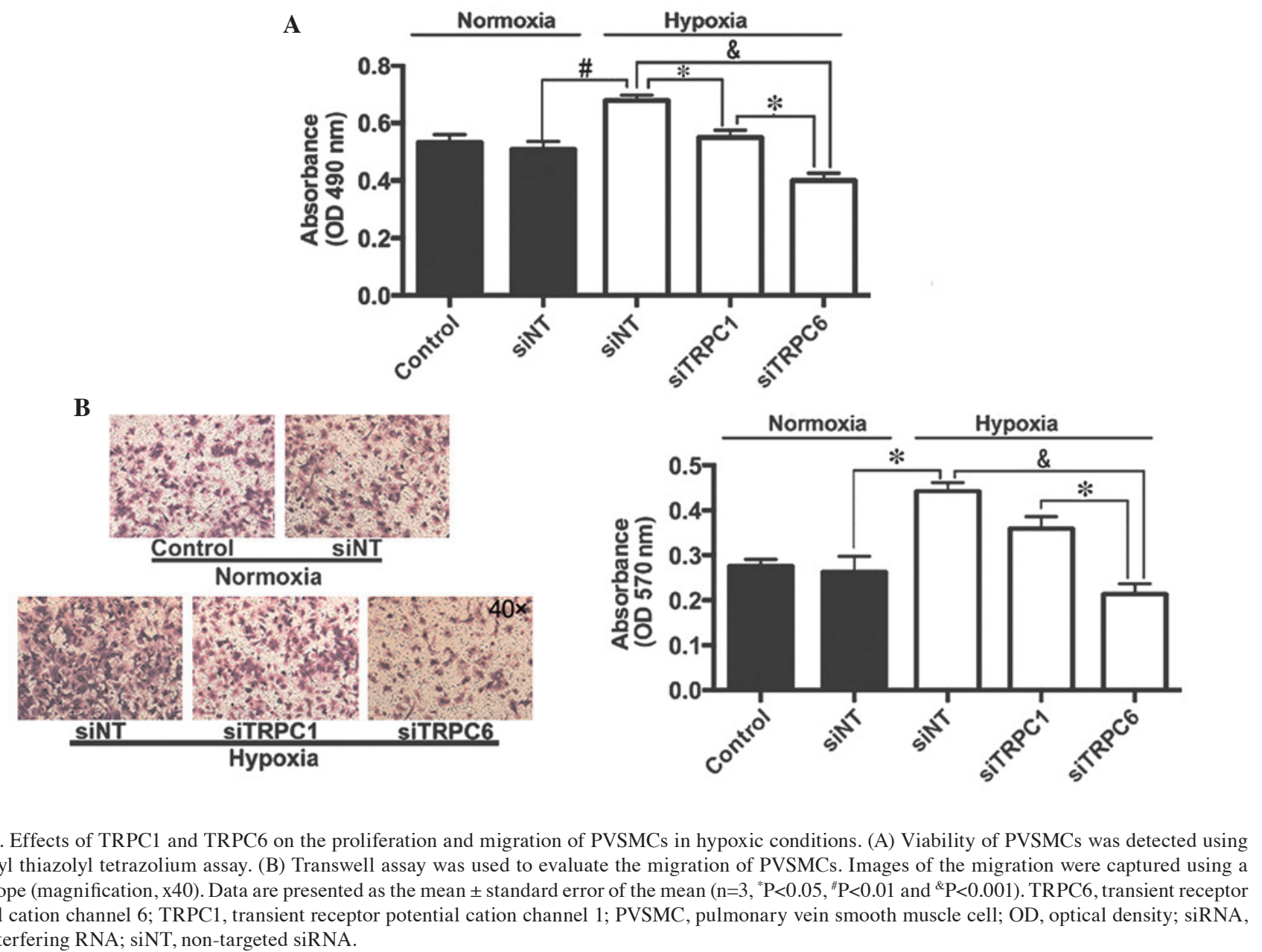

Figure 7. Effects of TRPC1 and TRPC6 on the proliferation and migration of PVSMCs in hypoxic conditions. (A) Viability of PVSMCs was detected using an methyl thiazolyl tetrazolium assay. (B) Transwell assay was used to evaluate the migration of PVSMCs. Images of the migration were captured using a microscope (magnification, $\mathrm{x} 40$ ). Data are presented as the mean \pm standard error of the mean $\left(\mathrm{n}=3,{ }^{*} \mathrm{P}<0.05,{ }^{\#} \mathrm{P}<0.01\right.$ and $\left.{ }^{\&} \mathrm{P}<0.001\right)$. TRPC6, transient receptor potential cation channel 6; TRPC1, transient receptor potential cation channel 1; PVSMC, pulmonary vein smooth muscle cell; OD, optical density; siRNA, small interfering RNA; siNT, non-targeted siRNA.

in $150 \mu \mathrm{l}$ DMSO, and the absorbance was measured by a Multiscan FC (Thermo Fisher Scientific, Inc., Waltham, MA, USA) at $490 \mathrm{~nm}$.

Migration assay. Migration was determined using the Transwell assay $(6.5-\mathrm{mm}$ polycarbonate membrane with 8.0- $\mu \mathrm{m}$ pores; Corning Inc., Corning, NY, USA). Briefly, suspensions containing $5 \times 10^{4}$ cells and fresh serum free media, were seeded on the upper chamber. The cells were allowed to migrate through the membrane to the lower surface for $6 \mathrm{~h}$. Cells on the upper surface of the membrane were scraped off with cotton swabs three times. Cells that had migrated to the lower surface were fixed in $4 \%$ paraformaldehyde, stained with $0.1 \%$ crystal violet and counted. Migrated cell numbers were calculated as the number of migrated cells per five different random fields. Cells were dissolved in $30 \%$ acetic acid and measured at $570 \mathrm{~nm}$ using a microplate reader (Thermo Fisher Scientific, Inc.). 
Statistical analysis. Data are presented as the mean \pm standard error of the mean. Unpaired t-tests were performed for pairwise comparisons of means. One-way analysis of variance, followed by the Tukey post-hoc test, was used for multiple comparisons. The data were analyzed using Prism 5.0 (GraphPad Software, Inc., La Jolla, CA, USA), and $\mathrm{P}<0.05$ was considered to indicate a statistically significant difference.

\section{Results}

Effects of $\mathrm{CH}$ on $\mathrm{PA}$ and right-side heart pressures. Rats were exposed to $\mathrm{CH}\left(10 \% \mathrm{O}_{2}\right)$ for 21 days. The MPAP increased from $11.10 \pm 1.14 \mathrm{mmHg}$ in normoxic rats to $18.42 \pm 0.77 \mathrm{mmHg}$ in hypoxic rats (Fig. 1A), and the RVSP increased from $18.23 \pm 1.57 \mathrm{mmHg}$ in normoxic rats to $29.53 \pm 3.57 \mathrm{mmHg}$ in hypoxic rats (Fig. 1B). In addition, $\mathrm{RV} /(\mathrm{LV}+\mathrm{S})$ increased from $0.23 \pm 0.04$ in normoxic rats to $0.37 \pm 0.04$ in hypoxic rats (Fig. 1C), and the hematocrit increased from $42.55 \pm 1.06 \%$ in normoxic rats to $51.87 \pm 1.90 \%$ in hypoxic rats (Fig. 1D).

TRPC1 and TRPC6 expression in the distal PA and PV tissue of normal and CHPH rats. Distal PAs and PVs were isolated from normal and CHPH rats. The mRNA and protein expression levels of TRPC1 and TRPC6 were detected by RT-qPCR and western blotting, respectively. As presented in Fig. 2A and B, the expression levels of TRPC1 and TRPC6 were increased in the distal PA of the CHPH rats, whereas only TRPC6 expression levels were increased in the distal PV of the $\mathrm{CHPH}$ rats, as compared with the controls (Fig. 2C and D).

TRPC1 and TRPC6 expression in cultured rat distal PVSMCs under normoxic and hypoxic conditions. Distal PVSMCs were isolated from normal rats and analyzed. As presented in Fig. 3A, PVSMCs were spindle-shaped and smooth muscle was $\alpha$-actin-positive. A high concentration $\mathrm{K}^{+}$solution $(60 \mu \mathrm{M})$ induced $\left[\mathrm{Ca}^{2+}\right]$ i elevation in PVSMCs, due to the opening of L-type VGCCs (37). As shown in Fig. 3B, nifedipine (5 $\mu \mathrm{M})$ inhibited $\mathrm{KCl}$-induced $\left[\mathrm{Ca}^{2+}\right]$ i elevation. Therefore, nifedipine was used for further experiments. The expression levels of TRPC1 and TRPC6 in rat distal PVSMCs cultured under normoxic and hypoxic conditions $\left(4 \% \mathrm{O}_{2}\right.$ for $\left.72 \mathrm{~h}\right)$ were examined by RT-qPCR and western blotting. The results demonstrated that TRPC6, but not TRPC1, was increased in response to hypoxia, as compared with the normoxic group (Fig. 3C and D). These results indicate that TRPC6, but not TRPC1, may be important in distal PVs in response to $\mathrm{CH}$.

Role of voltage-gated calcium channels (VGCCs) and TRPC6 blocker in hypoxia-induced $\mathrm{Ca}^{2+}$ entry in PVSMCs. Following 5 min exposure to hypoxia $\left(4 \% \mathrm{O}_{2}\right)$ a significant $\mathrm{Ca}^{2+}$ elevation was induced in cultured rat distal PVSMCs (Fig. 4A). Nifedipine $(20 \mu \mathrm{M})$ inhibited the hypoxia-induced $\left[\mathrm{Ca}^{2+}\right]_{\mathrm{i}}$ elevation by $46.5 \%$, whereas nifedipine $(20 \mu \mathrm{M})$ and SKF-96365 administered together inhibited the hypoxia-induced $\left[\mathrm{Ca}^{2+}\right]_{i}$ elevation by $64.2 \%$ (Fig. 4). These results indicate that VGCCs and TRPC6 may contribute to hypoxia-induced $\mathrm{Ca}^{2+}$ entry into PVSMCs.

Effects of TRPC6 knockdown on hypoxia-induced elevation of $\left[\mathrm{Ca}^{2+}\right] \mathrm{i}$ in rat distal PVSMCs. A specific siRNA against
TRPC6 (siTRPC6) was synthesized, and a siNT served as a control. Rat distal PVSMCs were isolated from normal rats and transfected with siRNA. TRPC6 protein expression levels were determined by western blotting $48 \mathrm{~h}$ post-transfection with siTRPC6 (Fig. 5A). As presented in Fig. 5B and C, the hypoxia-induced $\left[\mathrm{Ca}^{2+}\right]_{\mathrm{i}}$ elevation $\left(4 \% \mathrm{O}_{2}\right.$ for $\left.5 \mathrm{~min}\right)$ was decreased by siTRPC6 $(48 \mathrm{~h})$, indicating a role for TRPC6 in the hypoxia-induced elevation of $\left[\mathrm{Ca}^{2+}\right]_{\mathrm{i}}$ in PVSMCs. To determine the presence of functional TRPC6 in rat distal PVSMCs, 1-oleoyl-2-acetyl-sn-glycerol (OAG), an analogue of diacylglycerol (38), was used as a TRPC6 channel activator (6). OAG $(100 \mu \mathrm{M})$ induced $\left[\mathrm{Ca}^{2+}\right]_{\mathrm{i}}$ elevation, which was significantly attenuated by siTRPC6 (Fig. 5D), implicating TRPC6 as a functional ROCC in rat distal PVSMCs.

Hypoxia-induced $\mathrm{Ca}^{2+}$ elevation occurs via phospholipase $C$ (PLC) and AMPK. To determine the signaling pathway underlying TRPC6 activation, U73122 $(10 \mu \mathrm{M})$, an antagonist of PLC, and compound C (40 $\mu \mathrm{M})$, an antagonist of AMPK, were used during hypoxia-induced $\mathrm{Ca}^{2+}$ entry in rat distal PVSMCs. The results demonstrated that U73122 inhibited the hypoxia-induced $\mathrm{Ca}^{2+}$ response by $26.2 \%(\mathrm{n}=72, \mathrm{~N}=3, \mathrm{P}<0.05$; Fig. 6), whereas compound $\mathrm{C}$ inhibited the hypoxia-induced $\mathrm{Ca}^{2+}$ response by $68.1 \%(\mathrm{n}=76, \mathrm{~N}=3, \mathrm{P}<0.05$; Fig. $6 \mathrm{~B}$ and $\mathrm{C})$. These results indicate that the AMPK signaling pathway may contribute to hypoxia-induced $\mathrm{Ca}^{2+}$ elevation in PVSMCs.

Effects of TRPC1 and TRPC6 on hypoxia-induced proliferation and migration of rat distal PVSMCs. Cells were exposed to normoxic or hypoxic $\left(4 \% \mathrm{O}_{2}, 72 \mathrm{~h}\right)$ conditions and were transfected with siNT or siTRPC6. Proliferation and migration of PVSMCs was determined by methyl thiazolyl tetrazolium (MTT) and Transwell assays, respectively. As presented in Fig. 7A, hypoxia increased proliferation of PVSMCs from $0.51 \pm 0.03$ in the normoxic group to $0.68 \pm 0.02$ in the hypoxic group $(\mathrm{P}<0.05)$. Transfection with siTRPC1 only inhibited hypoxia-induced PVSMC proliferation by $19.1 \%$, whereas transfection with siTRPC6 inhibited hypoxia-induced PVSMC proliferation by $41.2 \%$, as compared with siNT-transfected cells exposed to hypoxia. Similarly, hypoxia increased migration of PVSMCs from $0.26 \pm 0.03$ in the normoxic group to $0.44 \pm 0.02$ in the hypoxic group $(\mathrm{P}<0.05)$. Transfection with siTRPC1 only inhibited hypoxia-induced PVSMC migration by $18.2 \%$, whereas transfection with siTRPC6 inhibited hypoxia-induced PVSMC migration by $52.3 \%$, as compared with siNT-transfected cells exposed to hypoxia (Fig. 7B).

\section{Discussion}

In the present study, the expression and function of TRPC1 and TRPC6 were examined in rat distal PVSMCs during $\mathrm{CH}$ in vivo and in vitro. The major results of the present study were as follows: i) TRPC6, not TRPC1, was functionally upregulated in rat PVs and PVSMCs in response to $\mathrm{CH}$; ii) upregulated TRPC6 was accompanied by OAG-induced $\mathrm{Ca}^{2+}$ entry; iii) SKF96365 and siTRPC6 attenuated hypoxia-induced cation entry; iv) hypoxia increased the proliferation and migration of PVSMCs, and this effect was attenuated by siTRPC6; and v) AMPK was suggested as the underlying pathway that links cellular energy status and TRPC6 activation. 
Hypoxia induces inflammation as well as $\left[\mathrm{Ca}^{2+}\right]_{\mathrm{i}}$ elevation, initiating PA contraction and remodeling $(39,40)$. However, PVs are affected prior to PAs when oxygen partial pressure in the pulmonary circulation decreases. PV contraction reportedly contributes to $\sim 50 \%$ of the total pulmonary resistance (41-43); therefore, it is necessary to determine the effects of hypoxia on PVs and to investigate the underlying molecular mechanisms. An elevated $\left[\mathrm{Ca}^{2+}\right]_{\mathrm{i}}$ is achieved predominantly by cation entry via VDCCs, ROCCs, SOCCs, or $\mathrm{Ca}^{2+}$ release from the sarcoplasmic reticulum. Previous studies have demonstrated that hypoxia induces enhanced store-operated $\mathrm{Ca}^{2+}$ entry and increases TRPC6 expression in rat PVSMCs $(15,21)$.

TRPC6 protein forms voltage-independent $\mathrm{Ca}^{2+}$-permeable cation channels, and is hypothesized to be a major component of ROCCs $(27,44)$. In a previous study, the majority of the hypoxia-induced $\left[\mathrm{Ca}^{2+}\right]_{\mathrm{i}}$ elevation in human PASMCs was due to cation entry via VDCCs and ROCCs (6), indicating that TRPC6 contributes to membrane depolarization and $\left[\mathrm{Ca}^{2+}\right]_{i}$ elevation. In addition, another previous study (15) detected TRPC1 and TRPC6 expression in rat PVs and distal PVSMCs. In the present study, expression of TRPC6, but not TRPC1, was increased in the PVs of CHPH rats, as well as PVSMCs exposed to hypoxia, implicating an important role for TRPC6 in hypoxia-induced cation entry.

Consistent with the results of previous studies regarding PVs (15) and PAs (6), the present study demonstrated that blockade of VGCCs with nifedipine in PVSMCs prevented hypoxia-induced $\left[\mathrm{Ca}^{2+}\right]_{\mathrm{i}}$ elevation by $46.5 \%$, whereas coadministration of nifedipine and SKF96365 (a TRPC blocker) prevented the hypoxia-induced $\left[\mathrm{Ca}^{2+}\right]_{\mathrm{i}}$ elevation by $64.2 \%$. To overcome the nonselectivity of the TRPC blocker, experiments using siTRPC6 to knockdown TRPC6 expression in VSMCs were conducted. The expression levels of TRPC6 and TRPC1 were examined by western blotting, in order to investigate the specific effect of TRPC6 gene knockdown. OAG, which is an analogue of diacylglycerol (38) and a TRPC6 activator, was used to analyze the functional knockdown of TRPC6. The results demonstrated that siTRPC6 significantly attenuated hypoxia-induced $\left[\mathrm{Ca}^{2+}\right]_{\mathrm{i}}$ elevation. These results suggested that TRPC6 may have a key role in the response of PVSMCs to hypoxia.

SMC proliferation and migration contribute to pulmonary vessel remodeling, in which $\left[\mathrm{Ca}^{2+}\right]_{\mathrm{i}}$ is pivotal $(5,6)$. In the present study, hypoxia increased the proliferation and migration of rat distal PVSMCs, and this effect was reduced by the knockdown of TRPC6. These results further indicated that TRPC6 may participate in PV remodeling, and may be considered a target for the treatment of $\mathrm{PH}$.

AMPK is important in cellular energy homeostasis. In a previous study, an AMPK antagonist attenuated hypoxia-induced $\left[\mathrm{Ca}^{2+}\right]_{i}$ elevations (45). Furthermore, it has previously been demonstrated that TRPC6 is activated via the AMPK signaling pathway and not via the PLC signaling pathway in human PASMCs (46). Consistent with human PASMCs, treatment with an AMPK antagonist in the present study attenuated hypoxia-induced $\left[\mathrm{Ca}^{2+}\right]_{i}$ elevation in rat PVSMCs, thus suggesting that AMPK may be a signal for TRPC6 in rat PVSMCs.

In conclusion, the present study demonstrated a functional role for hypoxia-induced TRPC6 upregulation in mediating
$\left[\mathrm{Ca}^{2+}\right]_{\mathrm{i}}$ elevation, and the proliferation and migration of rat distal PVSMCs. In addition, it was suggested that TRPC6 may be activated via the AMPK signaling pathway.

\section{Acknowledgements}

The present study was supported by grants from the National Natural Science Foundation of China (grant nos. 81170105 and 81370225).

\section{References}

1. Hyduk A, Croft JB, Ayala C, Zheng K, Zheng ZJ and Mensah GA: Pulmonary hypertension surveillance - United States, 1980-2002. MMWR Surveill Summ 54: 1-28, 2005.

2. George MG, Schieb LJ, Ayala C, Talwalkar A and Levant S: Pulmonary hypertension surveillance: United States, 2001 to 2010. Chest 146: 476-495, 2014.

3. Mehari A, Valle O and Gillum RF: Trends in pulmonary hypertension mortality and morbidity. Pulm Med 2014: 105864, 2014.

4. Naeije R: Pulmonary hypertension and right heart failure in chronic obstructive pulmonary disease. Proc Am Thorac Soc 2: 20-22, 2005.

5. Sylvester JT, Shimoda LA, Aaronson PI and Ward JP: Hypoxic pulmonary vasoconstriction. Physiol Rev 92: 367-520, 2012.

6. Tang C, To WK, Meng F, Wang Y and Gu Y: A role for receptor-operated $\mathrm{Ca}^{2+}$ entry in human pulmonary artery smooth muscle cells in response to hypoxia. Physiol Res 59: 909-918, 2010.

7. Salvaterra CG and Goldman WF: Acute hypoxia increases cytosolic calcium in cultured pulmonary arterial myocytes. Am J Physiol 264: L323-L328, 1993.

8. Shimoda LA, Sham JS, Shimoda TH and Sylvester JT: L-type $\left.\mathrm{Ca}^{(2+}\right)$ channels, resting $\left.\left[\mathrm{Ca}^{(2+}\right)\right](\mathrm{i})$, and ET-1-induced responses in chronically hypoxic pulmonary myocytes. Am J Physiol Lung Cell Mol Physiol 279: L884-L894, 2000.

9. Berridge MJ: Capacitative calcium entry. Biochem J 312: 1-11, 1995.

10. Lewis RS: The molecular choreography of a store-operated calcium channel. Nature 446: 284-287, 2007.

11. Lin MJ, Leung GP, Zhang WM, Yang XR, Yip KP, Tse CM and Sham JS: Chronic hypoxia-induced upregulation of store-operated and receptor-operated $\mathrm{Ca}^{2+}$ channels in pulmonary arterial smooth muscle cells: A novel mechanism of hypoxic pulmonary hypertension. Circ Res 95: 496-505, 2004.

12. Wang J, Weigand L, Lu W, Sylvester JT, Semenza GL and Shimoda LA: Hypoxia inducible factor 1 mediates hypoxia-induced TRPC expression and elevated intracellular $\mathrm{Ca}^{2+}$ in pulmonary arterial smooth muscle cells. Circ Res 98: 1528-1537, 2006.

13. Weissmann N, Dietrich A, Fuchs B, Kalwa H, Ay M, Dumitrascu R, Olschewski A, Storch U, Mederos y Schnitzler M, Ghofrani HA, et al: Classical transient receptor potential channel 6 (TRPC6) is essential for hypoxic pulmonary vasoconstriction and alveolar gas exchange. Proc Natl Acad Sci USA 103: 19093-19098, 2006.

14. Yoo HY, Park SJ, Seo EY, Park KS, Han JA, Kim KS, Shin DH, Earm YE, Zhang YH and Kim SJ: Role of thromboxane $\mathrm{A}_{2}$-activated nonselective cation channels in hypoxic pulmonary vasoconstriction of rat. Am J Physiol Cell Physiol 302: C307-C317, 2012.

15. Xu L, Chen Y, Yang K, Wang Y, Tian L, Zhang J, Wang EW, Sun D, Lu W and Wang J: Chronic hypoxia increases TRPC6 expression and basal intracellular $\mathrm{Ca}^{2+}$ concentration in rat distal pulmonary venous smooth muscle. PloS One 9: e112007, 2014.

16. Inoue R, Jensen LJ, Shi J, Morita H, Nishida M, Honda A and Ito Y: Transient receptor potential channels in cardiovascular function and disease. Circ Res 99: 119-131, 2006.

17. Groschner K, Rosker C and Lukas M: Role of TRP channels in oxidative stress. Novartis Found Symp 258: 222-230; discussion 231-225, 263-266, 2004.

18. Lu W, Wang J, Shimoda LA and Sylvester JT: Differences in STIM1 and TRPC expression in proximal and distal pulmonary arterial smooth muscle are associated with differences in $\mathrm{Ca}^{2+}$ responses to hypoxia. Am J Physiol Lung Cell Mol Physiol 295: L104-L113, 2008. 
19. Wang J, Shimoda LA and Sylvester JT: Capacitative calcium entry and TRPC channel proteins are expressed in rat distal pulmonary arterial smooth muscle. Am J Physiol Lung Cell Mol Physiol 286: L848-L858, 2004.

20. Resnik ER, Keck M, Sukovich DJ, Herron JM and Cornfield DN: Chronic intrauterine pulmonary hypertension increases capacitative calcium entry in fetal pulmonary artery smooth muscle cells. Am J Physiol Lung Cell Mol Physiol 292: L953-L959, 2007.

21. Peng G, Ran P, Lu W, Zhong N and Wang J: Acute hypoxia activates store-operated $\mathrm{Ca}^{\left({ }^{2+}\right)}$ entry and increases intracellular $\mathrm{Ca}\left({ }^{2+}\right)$ concentration in rat distal pulmonary venous smooth muscle cells. J Thorac Dis 5: 605-612, 2013.

22. Dietrich A, Kalwa H, Fuchs B, Grimminger F, Weissmann N and Gudermann T: In vivo TRPC functions in the cardiopulmonary vasculature. Cell Calcium 42: 233-244, 2007.

23. Inoue R, Okada T, Onoue H, Hara Y, Shimizu S, Naitoh S, Ito Y and Mori Y: The transient receptor potential protein homologue TRP6 is the essential component of vascular alpha(1)-adrenoceptor-activated $\mathrm{Ca}\left({ }^{2+}\right)$-permeable cation channel. Circ Res 88 325-332, 2001

24. Parekh AB and Putney JW Jr: Store-operated calcium channels. Physiol Rev 85: 757-810, 2005.

25. Villereal ML: Mechanism and functional significance of TRPC channel multimerization. Semin Cell Dev Biol 17: 618-629, 2006.

26. Boulay $\mathrm{G}: \mathrm{Ca}\left({ }^{2+}\right)$-calmodulin regulates receptor-operated $\mathrm{Ca}\left({ }^{2+}\right)$ entry activity of TRPC6 in HEK-293 cells. Cell Calcium 32: 201-207, 2002.

27. Wang J, Yang K, Xu L, Zhang Y, Lai N, Jiang H, Zhang Y, Zhong N, Ran P and Lu W: Sildenafil inhibits hypoxia-induced transient receptor potential canonical protein expression in pulmonary arterial smooth muscle via cGMP-PKG-PPAR $\gamma$ axis Am J Respir Cell Mol Biol 49: 231-240, 2013.

28. Hasebe N, Onodera S, Yamashita H, Kawamura Y, Haneda T and Tobise K: Site of hypoxic pulmonary vasoconstriction in pulsatile perfused canine lung lobes. Jpn Circ J 56: 837-846, 1992.

29. Gao Y and Raj JU: Role of veins in regulation of pulmonary circulation. Am J Physiol Lung Cell Mol Physiol 288: L213-L226, 2005.

30. Raj JU, Hillyard R, Kaapa P, Gropper M and Anderson J: Pulmonary arterial and venous constriction during hypoxia in 3- to 5-wk-old and adult ferrets. J Appl Physiol (1985) 69: 2183-2189, 1990.

31. Zhao Y, Packer CS and Rhoades RA: Pulmonary vein contracts in response to hypoxia. Am J Physiol 265: L87-L92, 1993.

32. National Research Council (US) Institute for Laboratory Animal Research: Guide for the Care and Use of Laboratory Animals. Washington (DC), 1996.
33. Yan J, Chen R, Liu P and Gu Y: Docosahexaenoic acid inhibits development of hypoxic pulmonary hypertension: in vitro and in vivo studies. Int J Cardiol 168: 4111-4116, 2013.

34. Peng G, Wang J, Lu W and Ran P: Isolation and primary culture of rat distal pulmonary venous smooth muscle cells. Hypertens Res 33: 308-313, 2010.

35. Ohba T, Watanabe H, Murakami M, Takahashi Y, Iino K, Kuromitsu S, Mori Y, Ono J, Iijima T and Ito H: Upregulation of TRPC1 in the development of cardiac hypertrophy. J Mol Cell Cardiol 42: 498-507, 2007.

36. Thebault S, Zholos A, Enfissi A, Slomianny C, Dewailly E, Roudbaraki M, Parys J and Prevarskaya N: Receptor-operated $\mathrm{Ca}^{2+}$ entry mediated by TRPC3/TRPC6 proteins in rat prostate smooth muscle (PS1) cell line. J Cell Physiol 204: 320-328, 2005.

37. Green KN, Boyle JP and Peers C: Hypoxia potentiates exocytosis and $\mathrm{Ca}^{2+}$ channels in PC12 cells via increased amyloid beta peptide formation and reactive oxygen species generation. J Physiol 541: 1013-1023, 2002

38. Livak KJ and Schmittgen TD: Analysis of relative gene expression data using real-time quantitative PCR and the 2(-Delta Delta C(T)) Method. Methods 25: 402-408, 2001

39. Stenmark KR, Fagan KA and Frid MG: Hypoxia-induced pulmonary vascular remodeling: Cellular and molecular mechanisms. Circ Res 99: 675-691, 2006.

40. Biddlestone J, Bandarra D and Rocha S: The role of hypoxia in inflammatory disease (Review). Int J Mol Med 35: 859-869, 2015.

41. Bonnet S and Archer SL: Potassium channel diversity in the pulmonary arteries and pulmonary veins: Implications for regulation of the pulmonary vasculature in health and during pulmonary hypertension. Pharmacol Ther 115: 56-69, 2007.

42. Schindler MB, Hislop AA and Haworth SG: Postnatal changes in pulmonary vein responses to endothelin-1 in the normal and chronically hypoxic lung. Am J Physiol Lung Cell Mol Physiol 292: L1273-1279, 2007.

43. Wang TM, Luk HN, Sheu JR, Wu HP and Chiang CE: Inducibility of abnormal automaticity and triggered activity in myocardial sleeves of canine pulmonary veins. Int J Cardiol 104: 59-66, 2005.

44. Beech DJ: Emerging functions of 10 types of TRP cationic channel in vascular smooth muscle. Clinical Exp Pharmacol Physiol 32: 597-603, 2005.

45. Wyatt CN, Mustard KJ, Pearson SA, Dallas ML, Atkinson L, Kumar P, Peers C, Hardie DG and Evans AM: AMP-activated protein kinase mediates carotid body excitation by hypoxia. J Biol Chem 282: 8092-8098, 2007.

46. Tang C, To WK, Meng F, Wang Y and Gu Y: A role for receptor operated $\mathrm{Ca} 2+$ entry in human pulmonary artery smooth muscle cells in response to hypoxia. Physiol Res 59: 909 918, 2010. 